\title{
Effect of day length and exogenous melatonin on chemical composition of sheep milk
}

\author{
Edyta Molik1, Genowefa Bonczar², Aneta Żebrowska², Tomasz Misztal', Henryk \\ Pustkowiak $^{3}$ and Dorota Zięba'
}

'Department of Swine and Small Ruminant Breeding, Biotechnology and Genomic Laboratory, ${ }^{2}$ Department of Animal Product Processing, ${ }^{3}$ Department of Cattle Breeding, Agricultural University, Krakow, Poland, ${ }^{4}$ Department of Endocrinology, Kielanowski Institute of Animal Physiology and Nutrition, Polish Academy of Sciences, Warsaw, Poland

\begin{abstract}
Changes in day length are a major factor in the productivity of farm animals showing reproductive seasonality. Parameters of milk production in sheep and goats are dependent on melatonin and prolactin concentrations. Changes in the prolactin secretion in lactating sheep have an effect on the amount of milk produced, synthesis of milk proteins, fat and immunoglobulins (i.e. milk composition). In the end the quality and commercial value of milk is determined as well. The aim of this study was therefore to find out the effect of day length and exogenous melatonin on the chemical composition of milk and the level of fatty acids. Subjects were 60 Polish Longwool Sheep. Animals were randomly assigned to three groups, Group I ( $n=20)$ - ewes raised under natural day length; Group II $(n=20)$ ewes raised under natural day length and were implanted with melatonin; Group III ( $n=20)$ - ewes exposed to an artificially short photoperiod (16D:8L). Sheep were milked twice daily using the Alfa Laval Agri milking machine. Composite milk samples were collected every 28 days to determine chemical composition and fatty acid content. The results obtained showed that the administration of exogenous melatonin and the simulation of a short-day photoperiod during the summer period had significant effects on the milk levels of solids, protein, fat and lactose, and on the fatty acid content of sheep milk.
\end{abstract}

Keywords: sheep, milk, chemical composition, exogenous melatonin, day length

\section{Zusammenfassung}

\section{Auswirkung von Tageslänge und exogenem Melatonin auf die chemische Zusammensetzung von Schafsmilch}

Änderungen in der Tageslänge sind ein wesentlicher Faktor bei der Produktivität von Nutztieren, die eine sich wiederholenden Saisonabhängigkeit zeigt. Die Parameter für die Milchproduktion in Schafen und Ziegen sind von der Melatonin- und Prolaktinkonzentration abhängig. Änderungen in der Prolaktin-Sekretion in laktierenden Schafen haben Auswirkung auf die produzierte Milchmenge, die Synthese von Milchproteinen, Fett und Immunglobulinen (d. h. auf die Milchzusammensetzung). Schließlich werden auch Qualität und Verkaufswert der Milch bestimmt. Darum bestand das Ziel dieser Studie darin, die Auswirkung von Tageslänge und exogenem Melatonin auf die chemische Zusammensetzung der Milch auf dem Niveau 
der Fettsäuren festzustellen. Die Versuchsobjekte waren 60 Polnische Langwolleschafe. Die Tiere wurden statistisch auf drei Gruppen verteilt, Gruppe I ( $n=20)$ - weibliche Schafe, die unter natürlicher Tageslänge aufgezogen wurden; Gruppe II ( $n=20)$ - weibliche Schafe, die unter natürlicher Tageslänge aufgezogenen wurden und denen Melatonin implantiert wurde; Gruppe III ( $n=20)$ - weibliche Schafe, die einer kürzeren Kunstlichtperiode ausgesetzt waren (16D:8L). Die Schafe wurden unter Verwendung der Alfa-Laval-Agri-Melkmaschine zweimal am Tag gemolken. Alle 28 Tage wurden Milch-Sammelproben gesammelt, um die chemische Zusammensetzung und den Fettsäuregehalt zu bestimmen. Die erhaltenen Ergebnisse zeigten, dass die Verabreichung von exogenem Melatonin und die Simulierung einer Kurztag-Lichtperiode während des Sommerzeitraums bei Schafsmilch signifikante Auswirkungen auf die Konzentrationen von Feststoffen, Protein, Fett und Laktose und auf den Fettsäuregehalt in der Milch hatten.

Schlüsselwörter: Schafe, Milch, chemische Zusammensetzung, exogenes Melatonin, Tageslänge

\section{Introduction}

The growing interest in sheep milk products and the promotion of their health benefits may be what is contributing to the development of sheep farming (Ciuryk et al. 2004, Fischer et al. 2007, Molik et al. 2008). The healthy dietary qualities of sheep milk are due to its high nutrient content (Anifantakis 1986, Haenlein 1996, Żegarska 1998, Pakulski et al. 2006). Sheep milk is characterized by lower cholesterol content, more beneficial composition of fatty acids and better hygiene (lower Somatic Cell Content) (Bonczar 2006a, Bonczar 2006b, Borys \& Pisulewski, 2001, Olechnowicz et al. 2010). Sheep milk is also prized for its dietetic and curative properties because it contains orotic acid and amygdalin, which are recognized as having anticarcinogenic properties (Sawicka et al. 1987). The dietetic qualities of sheep milk and the increased interest in cheeses with very good taste and nutritional properties require that this product be marketed all year round (Bonczar 1989, 2006b, Borys et al. 2006, Ciuryk et al. 2004, Szumacher-Srabel et al. 2001, Wasilewicz-Niedbalska et al. 2001, Wójtowski et al. 2001). However, milk form late in the production season can have manufacturing properties that differ from those of early and mid-season milk (Lucey 1996). Seasonal variation in milk composition has been associated with several factors among which environmental condition such a photoperiod can play an important role. A study by Molik et al. (2007) showed that the milkyield of sheep can be determined by day length. Sheep entering lactation during the short day regime produced $50 \%$ less milk than sheep milked during the long day. The differences found in milk yield resulted from changes in melatonin and prolactin concentrations. In shortday animals exposed to decreasing photoperiod, melatonin concentrations were found to increase and prolactin secretion was found to decline (Misztal et al. 1996, Molik et al. 2006). Changes in prolactin secretion in lactating sheep influence the amount of milk produced. Identifying the relationships between photoperiod and lactation length may help to explain the role of melatonin in regulating milk synthesis and modulating its chemical composition. The aim of this study was to determine the effect of day length and exogenous melatonin on the chemical composition of sheep milk. 


\section{Materials and methods}

Animals

The study was carried out at the Experimental Station of the Department of Swine and Small Ruminant Breeding of the Agricultural University in Krakow, Poland. Sixty Polish Longwool ewes were used in the experiment. Longwool ewes were chosen as this is a breed that exhibits strong seasonal reproduction activities. The ewes were 4-5 years age and recorded a mean body weight of $60 \pm 5 \mathrm{~kg}$. All animals were housed in individual pens under a natural photoperiodic and thermoperiodic environment (longitude: $19^{\circ} 57^{\prime} \mathrm{E}$, latitude: $50^{\circ} 04^{\prime} \mathrm{N}$ ). Ewes recorded an average Body Condition Score (BCS) of 3 (on a scale from 0-5; where $\mathrm{O}=$ emaciated and $5=$ obese) (Russel et al. 1969).

Throughout the experiment, sheep were fed according to their physiological status. Thus from the preparation for mating, to the end of the 4th month of pregnancy, all ewes were fed in accordance with the standards of the National Research Institute of Animal Production (Krakow - Balice, Norms, 1993), based on the seasonal feeds available (forage pasture, hay and feed concentrate). From the 5th month of pregnancy, to the end of experiment, sheep received an additional $1.5 \mathrm{~kg}$ pelleted diet per day (7.5 MJ net energy and $220 \mathrm{~g}$ crude protein). Supplementary hay was also provided. All animals had free access to water and a mineral lick.

\section{Experimental design}

Ewes oestrous cycle was synchronized using Chronogest sponges (Chronogest, Intervet International, Boxmeer, The Netherlands). All groups of sheep were mated between 15 and 30 September and lambed in the second half of February. Lambs were reared with mothers for 56 days after which they were weaned and mothers were used for milking. On day 57, the ewes were divided into three groups: Group I ( $n=20)$ - ewes raised under natural day length; Group II $(n=20)$ ewes raised under natural day length and were implanted with melatonin as slow-release implants (Ceva Animal, France), implanted subcutaneously behind the ears. Each implant contained $18 \mathrm{mg}$ of melatonin; Group III ( $\mathrm{n}=20)$ - ewes exposed to an artificially short photoperiod (16D:8L). After weaning, ewes were milked twice daily with an Alfa-Laval milker until drying. Milk yield was recorded individually at 10-day intervals.

To determine chemical composition, composite milk samples were collected every 28 days from each group of sheep. Milk solids, protein, fat and lactose were analysed according to the method of Budsławski (1981).

Fatty acid content was determined by gas chromatography (chromatograph PYE-UNICAM series 104 with chromatography column SUPELCOWAX $10.30 \mathrm{~m}, \varnothing 0.53 \mathrm{~mm}, 1.0 \mu \mathrm{m}$ ) following the method described by Mann (1964).

Throughout the experiment, sheep from groups I and II were kept indoors with outdoor access. Throughout lactation, sheep from group III were housed indoors on an area of $20 \mathrm{~m}^{2}$ under artificial short day (16D:8L).

\section{Statystical analysis}

Chemical compositions and fatty acids concentrations are expressed as a mean \pm SEM. The effects of the treatments chemical compositions milk were analyzed by one-way analysis of 
variance (ANOVA) followed by the post-hoc least significant difference test, using the SAS 8.1 (SAS 2000). The differences in the parameters of lactations between groups were assayed by the nonparametric ANOVA rank Kruskal-Wallis test, using the same SAS software.

\section{Results}

The results obtained showed significant $(P \leq 0.01)$ differences in milk solids content in the second month of milking. In the next months of milking, milk solids content increased with significant differences $(P \leq 0.05)$ (Table 1).

Table 1

Changes of chemical composition in sheep's milk

\begin{tabular}{|c|c|c|c|c|c|c|}
\hline \multirow[t]{4}{*}{ Traits } & \multicolumn{6}{|c|}{ Group } \\
\hline & \multirow{2}{*}{\multicolumn{2}{|c|}{$\begin{array}{c}\text { Group I } \\
\text { Control Group }\end{array}$}} & \multirow{2}{*}{\multicolumn{2}{|c|}{$\begin{array}{l}\text { Group II } \\
\text { Exogenous melatonin }\end{array}$}} & \multirow{2}{*}{\multicolumn{2}{|c|}{$\begin{array}{l}\text { Group II } \\
\text { 16D: 8L }\end{array}$}} \\
\hline & & & & & & \\
\hline & $\bar{x}$ & $S(X)$ & $\bar{x}$ & $S(X)$ & $\bar{x}$ & $S(X)$ \\
\hline \multicolumn{7}{|c|}{ Collection 1 - April } \\
\hline Dry matter, \% & 18.26 & 0.2 & 18.09 & 0.2 & 17.46 & 0.2 \\
\hline Protein, \% & 5.47 & 0.07 & 5.83 & 0.49 & 6.19 & 0.04 \\
\hline Fat, $\%$ & $7.92^{\mathrm{A}}$ & 0.02 & $7.17^{\mathrm{B}}$ & 0.01 & $5.93^{C}$ & 0.02 \\
\hline Lactose, \% & $3.87^{c}$ & 0.07 & $4.09^{B}$ & 0.03 & $4.32^{\mathrm{A}}$ & 0.01 \\
\hline \multicolumn{7}{|l|}{ Collection 2 - May } \\
\hline Dry matter, \% & $19.2^{\mathrm{B}}$ & 0.01 & $15.7^{\mathrm{A}}$ & 0.06 & $21.8^{\mathrm{C}}$ & 0.02 \\
\hline Protein, $\%$ & $6.6^{\mathrm{B}}$ & 0.01 & $5.86^{A}$ & 0.02 & $6.87^{\mathrm{B}}$ & 0.01 \\
\hline Fat, $\%$ & $7.43^{\mathrm{B}}$ & 0.01 & $5.21^{c}$ & 0.02 & $9.8^{\mathrm{A}}$ & 0.01 \\
\hline Lactose, \% & $4.29^{A}$ & 0.01 & $4.23^{B}$ & 0.04 & $4.02^{C}$ & 0.01 \\
\hline \multicolumn{7}{|c|}{ Collection 3 - June } \\
\hline Dry matter, \% & $19.2^{\mathrm{b}}$ & 0.02 & $19.0^{\mathrm{b}}$ & 0.06 & $20.0^{\mathrm{a}}$ & 0.02 \\
\hline Protein, $\%$ & $7.1^{\mathrm{b}}$ & 0.07 & $7.15^{b}$ & 0.01 & $7.5^{\mathrm{a}}$ & 0.07 \\
\hline Fat, $\%$ & 7.01 & 0.04 & 6.73 & 0.04 & 7.46 & 0.02 \\
\hline Lactose, $\%$ & $4.01^{B}$ & 0.01 & $4.09^{A}$ & 0.02 & $3.88^{\mathrm{C}}$ & 0.01 \\
\hline \multicolumn{7}{|l|}{ Collection 4 - July } \\
\hline Dry matter, \% & $20.8^{\mathrm{b}}$ & 0.06 & $20.84^{b}$ & 0.01 & $20.31^{\mathrm{a}}$ & 0.05 \\
\hline Protein, $\%$ & $6.8^{\mathrm{B}}$ & 0.04 & $7.8^{\mathrm{A}}$ & 0.01 & $7.09^{B}$ & 0.01 \\
\hline Fat, $\%$ & $8.81^{\mathrm{A}}$ & 0.08 & $7.75^{\mathrm{B}}$ & 0.01 & $8.02^{\mathrm{B}}$ & 0.03 \\
\hline Lactose, $\%$ & $4.8^{\mathrm{A}}$ & 0.01 & $4.17^{\mathrm{B}}$ & 0.01 & $4.17^{B}$ & 0.05 \\
\hline
\end{tabular}

$\mathrm{A}, \mathrm{B}, \mathrm{C}$ mean indicates with the different letters in verse shows differences at $P \leq 0.01,{ }^{a, b}$ mean indicates with the different letters in verse shows differences at $P \leq 0.05$

The highest protein content at the second sampling was characteristic of the milk from sheep housed under 16D:8L conditions $(6.87 \pm 0.01 \%)$, whereas the milk from melatoninimplanted sheep contained significantly $(P \leq 0.01)$ less protein $(5.86 \pm 0.02 \%)$ (Table 1$)$. In June, a significantly $(\mathrm{P} \leq 0.05)$ higher protein content was found in the milk from sheep maintained under $16 \mathrm{D}: 8 \mathrm{~L}$ conditions $(7.5 \pm 0.07 \%)$, whereas the milk from the control group and melatoninimplanted sheep contained less protein $(7.1 \pm 0.07 \%$ and $7.15 \pm 0.01 \%$, respectively). In the fourth month of milking, a significantly $(P \leq 0.01)$ higher protein content was characteristic of the milk from melatonin-implanted sheep $(7.8 \pm 0.01 \%)$, with less protein contained in the milk from $16 \mathrm{D}: 8 \mathrm{~L}(7.09 \pm 0.01 \%)$ and the control group of sheep $(6.8 \pm 0.04 \%)$. When analysing 
the changes in fat content, significant differences were found in the first month of milking (Table 1). During the second sampling fat content was significantly $(P \leq 0.01)$ highest for the milk from sheep maintained under 16D:8L conditions $(9.8 \pm 0.01 \%)$, with the lowest amount of fat contained in the milk from melatonin-implanted sheep (5.21 $\pm 0.02 \%)$. In July, fat content was the highest in the control group of sheep $(8.81 \pm 0.08 \%)$. Significantly $(P \leq 0.01)$ lower amounts of fat were found in the milk from 16D:8L (8.02 $\pm 0.03 \%)$ and melatonin-implanted sheep $(7.75 \pm 0.01 \%)$. The analysis of changes in milk lactose content revealed significant $(P \leq 0.01)$ differences between the analysed groups.

Changes in the fatty acid content in the milk of sheep from groups I, II and III in the first month of milking are shown in Table 2 . The significantly $(P \leq 0.05)$ highest content of saturated fatty acids was characteristic of the milk from 16D:8L sheep (7.79 $\pm 2.6 \%$ ), with the least saturated fatty acids found in the milk from melatonin-implanted sheep $(7.24 \pm 2.6 \%)$. When analysing changes in the content of unsaturated fatty acids, significant $(P \leq 0.05)$ differences were observed between the group of melatonin-implanted sheep $(3.28 \pm 1.9 \%)$ and the $16 \mathrm{D}: 8 \mathrm{~L}$ group $(2.53 \pm 1.4 \%)$. In the first month of milking, the highest content of polyunsaturated fatty acids was characteristic of the milk from sheep implanted with melatonin (1.67 $\pm 0.9 \%$; Table 2$)$.

Table 2

Changes of fat acid in sheep's milk in April, \%

\begin{tabular}{|c|c|c|c|c|c|c|}
\hline \multirow[t]{3}{*}{ Fatty acid } & \multicolumn{6}{|c|}{ Collection 1- April } \\
\hline & \multicolumn{2}{|c|}{$\begin{array}{c}\text { Group I } \\
\text { Control Group }\end{array}$} & \multicolumn{2}{|c|}{$\begin{array}{c}\text { Group II } \\
\text { Exogenous melatonin }\end{array}$} & \multicolumn{2}{|c|}{$\begin{array}{l}\text { Group II } \\
\text { 16D: 8L }\end{array}$} \\
\hline & $\bar{x}$ & $S(X)$ & $\bar{x}$ & $S(X)$ & $\bar{x}$ & $S(X)$ \\
\hline C 4:0 & $2.97^{\mathrm{a}}$ & 1.1 & $3.25^{\mathrm{b}}$ & 1.7 & 3.15 & 1.6 \\
\hline C 6:0 & $2.71^{\mathrm{a}}$ & 0.9 & 2.82 & 1.4 & $2.88^{\mathrm{b}}$ & 1.5 \\
\hline C 8:0 & 2.80 & 0.9 & 2.94 & 1.8 & 2.89 & 1.6 \\
\hline C $10: 0$ & 9.96 & 3.1 & $9.78^{\mathrm{a}}$ & 4.2 & $10.94^{\mathrm{b}}$ & 6.3 \\
\hline C 12:0 & $6.42^{c}$ & 2.4 & $5.98^{\mathrm{a}}$ & 1.9 & $7.31^{\mathrm{b}, \mathrm{d}}$ & 3.9 \\
\hline C 14:0 & $14.08^{\mathrm{a}, \mathrm{c}}$ & 5.3 & $12.54^{\mathrm{b}, \mathrm{e}}$ & 5.9 & $15.54^{\mathrm{d}, \mathrm{f}}$ & 7.4 \\
\hline C 15:0 & 1.08 & 0.7 & 1.10 & 0.6 & 1.027 & 0.6 \\
\hline C $16: 0$ & $27.60^{\mathrm{b}}$ & 9.3 & $26.59^{\mathrm{a}, \mathrm{c}}$ & 11.4 & $29.19^{d}$ & 10.3 \\
\hline C $17: 0$ & 0.47 & 0.03 & 0.56 & 0.04 & 0.40 & 0.03 \\
\hline C 18:0 & $5.97^{b}$ & 1.6 & $6.83^{d}$ & 2.3 & $4.54^{\mathrm{a}, \mathrm{c}}$ & 1.7 \\
\hline C $10: 1$ & 0.45 & 0.03 & 0.39 & 0.01 & 0.51 & 0.04 \\
\hline C 14:1 & $0.43^{b}$ & 0.02 & $0.29^{a, c}$ & 0.01 & $0.516^{d}$ & 0.04 \\
\hline C 16:1 & $1.45^{\mathrm{a}}$ & 0.8 & $1.12^{\mathrm{b}}$ & 0.8 & 1.30 & 0.7 \\
\hline C 17:1 & 0.23 & 0.4 & 0.26 & 0.02 & 0.18 & 0.01 \\
\hline C $18: 1$ & $15.76^{b}$ & 7.4 & $17.54^{d}$ & 6.9 & $12.85^{\mathrm{a}, \mathrm{c}}$ & 5.9 \\
\hline C18:2 & 2.05 & 0.9 & $2.45^{b}$ & 1.3 & $1.89^{\mathrm{a}}$ & 0.7 \\
\hline C $18: 3$ & $0.66^{d}$ & 0.04 & $0.90^{\mathrm{a}, \mathrm{c}}$ & 0.05 & $0.46^{b}$ & 0.03 \\
\hline CLA & $0.61^{b}$ & 0.04 & $0.68^{d}$ & 0.02 & $0.49^{a, c}$ & 0.03 \\
\hline SFA & 7.4 & 2.8 & $7.24^{\mathrm{a}}$ & 2.6 & $7.79^{b}$ & 2.9 \\
\hline MUFA & 3.01 & 1.7 & $3.28^{b}$ & 1.9 & $2.53^{\mathrm{a}}$ & 1.4 \\
\hline PUFA & 1.36 & 0.8 & $1.67^{\mathrm{a}}$ & 0.9 & $1.18^{b}$ & 1.1 \\
\hline
\end{tabular}

CLA: conjugated linoleic acid, SFA: saturated fatty acid, MUFA: monounsaturated fatty acid, PUFA: polyunsaturated fatty acid 
Significantly $(P \leq 0.05)$ lower amounts of polyunsaturated fatty acids were found in the milk from sheep housed under 16D:8L conditions (1.18 $\pm 1.1 \%)$. Conjugated linoleic acid (CLA) was the most abundant in the milk from melatonin-implanted sheep $(0.68 \pm 0.02 \%)$. Significantly (P£0.05) less CLA was contained in the milk from 16D:8L sheep $(0.49 \pm 0.03 \%)$ and the control group of sheep $(0.61 \pm 0.04 \%)$.

When analysing changes in the content of saturated fatty acids in the second month of milking (Table 3), significant $(P \leq 0.05)$ differences were found between sheep kept under 16D:8L conditions (7.98 $\pm 3.2 \%$ ) and the control group (7.69 $\pm 3.1 \%$ ) (Table 3). There were also significant $(P \leq 0.05)$ differences in the content of unsaturated fatty acids between these groups (2.26 $\pm 1.3 \%$ vs. $2.62 \pm 1.9 \%)$.

Table 3

Changes of fat acid in sheep's milk in May, \%

\begin{tabular}{|c|c|c|c|c|c|c|}
\hline \multirow[t]{3}{*}{ Fatty acid } & \multicolumn{6}{|c|}{ Collection 2- May } \\
\hline & \multicolumn{2}{|c|}{$\begin{array}{c}\text { Group I } \\
\text { Control Group }\end{array}$} & \multicolumn{2}{|c|}{$\begin{array}{c}\text { Group II } \\
\text { Exogenous melatonin }\end{array}$} & \multicolumn{2}{|c|}{$\begin{array}{l}\text { Group II } \\
\text { 16D: 8L }\end{array}$} \\
\hline & $\bar{x}$ & $S(X)$ & $\bar{x}$ & $S(X)$ & $\bar{x}$ & $S(X)$ \\
\hline C $4: 0$ & $2.68^{\mathrm{A}}$ & 1.2 & 2.76 & 1.8 & $2.95^{\mathrm{B}}$ & 1.6 \\
\hline C $6: 0$ & 2.53 & 1.1 & 2.56 & 1.5 & 2.70 & 1.5 \\
\hline C 8:0 & 2.72 & 1.4 & 2.78 & 1.9 & 2.87 & 1.7 \\
\hline C 10:0 & $10.59^{\mathrm{a}}$ & 3.3 & 10.87 & 3.8 & $11.56^{\mathrm{b}}$ & 6.4 \\
\hline C 12:0 & $7.35^{\mathrm{a}}$ & 2.4 & 7.68 & 2.9 & $8.21^{\mathrm{b}}$ & 3.8 \\
\hline C 14:0 & $15.73^{\mathrm{a}, \mathrm{c}}$ & 7.3 & $16.43^{b}$ & 7.4 & $16.84^{d}$ & 7.6 \\
\hline C 15:0 & 1.11 & 0.9 & 1.10 & 0.8 & 1.13 & 0.8 \\
\hline C $16: 0$ & 29.14 & 9.8 & 29.62 & 11.6 & 30.02 & 12.3 \\
\hline C 17:0 & 0.36 & 0.04 & 0.36 & 0.03 & 0.31 & 0.02 \\
\hline C $18: 0$ & $4.67^{b}$ & 1.6 & 3.87 & 2.4 & $3.21^{\mathrm{a}}$ & 1.8 \\
\hline C 10:1 & 0.52 & 0.06 & 0.54 & 0.02 & 0.62 & 0.03 \\
\hline C $14: 1$ & 0.59 & 0.05 & 0.59 & 0.03 & 0.75 & 0.04 \\
\hline C $16: 1$ & $1.86^{\mathrm{b}}$ & 0.8 & $1.62^{\mathrm{a}, \mathrm{c}}$ & 0.9 & $1.84^{d}$ & 0.7 \\
\hline C $17: 1$ & 0.20 & 0.4 & 0.20 & 0.01 & 0.18 & 0.01 \\
\hline C $18: 1$ & $13.08^{b}$ & 7.4 & $12.71^{\mathrm{d}}$ & 6.7 & $10.60^{a, c}$ & 6.9 \\
\hline C18:2 & 1.72 & 0.9 & 1.87 & 0.9 & 1.50 & 0.7 \\
\hline C $18: 3$ & 0.37 & 0.04 & 0.38 & 0.04 & 0.28 & 0.02 \\
\hline CLA & 0.49 & 0.02 & 0.43 & 0.01 & 0.40 & 0.03 \\
\hline SFA & $7.69^{a}$ & 3.1 & 7.8 & 2.8 & $7.98^{\mathrm{b}}$ & 3.2 \\
\hline MUFA & $2.62^{\mathrm{b}}$ & 1.9 & 2.56 & 1.8 & $2.26^{\mathrm{a}}$ & 1.3 \\
\hline PUFA & 1.05 & 0.7 & 1.13 & 0.8 & 0.9 & 0.04 \\
\hline
\end{tabular}

CLA: conjugated linoleic acid, SFA: saturated fatty acid, MUFA: monounsaturated fatty acid, PUFA: polyunsaturated fatty acid

The highest CLA content in the third month of milking was characteristic of the milk from the control group of sheep $(0.71 \pm 0.04 \%)$ and the lowest CLA was contained in the milk from melatonin-implanted sheep $(0.35 \pm 0.01 \%)$, with significant $(P \leq 0.05)$ differences (Table 4). Significantly $(P \leq 0.05)$ the highest content of saturated fatty acids was characteristic of the milk from melatonin-treated sheep $(8.06 \pm 3.1 \%)$. Meanwhile, the highest content of unsaturated fatty acids was found in the milk from the control group of sheep (2.71 $\pm 1.9 \%)$. Significantly $(P \leq 0.05)$ lower amounts of these acids were contained in the milk from melatonin-implanted 
sheep $(2.38 \pm 1.7 \%)$. In the last month of milking (July) the highest CLA content was characteristic of the milk from the control group of sheep $(0.96 \pm 0.3 \%)$, whereas the milk from sheep maintained under 16D:8L conditions had the lowest CLA content $(0.38 \pm 0.02 \%)$, with significant (P£0.05) differences. In July (Table 5), the milk from the control group of sheep continued to have the highest content of unsaturated fatty acids ( $2.93 \pm 1.7 \%)$. The milk from sheep maintained under a 16D:8L regime had a significantly (P£0.05) lower content of these acids ( $2.44 \pm 0.8 \%)$. There were significant (P£0.05) differences in the polyunsaturated fatty acid content of milk between the control group of sheep $(1.68 \pm 0.6 \%)$ and those raised under short days (1.20 $\pm 0.1 \%)$.

Table 4

Changes of fat acid in sheep's milk in June, \%

\begin{tabular}{lcccccc}
\hline Fatty acid & \multicolumn{2}{c}{ Group I } & \multicolumn{2}{c}{$\begin{array}{c}c \\
\text { Group II }\end{array}$} & \multicolumn{2}{c}{ Group II } \\
& \multicolumn{1}{c}{ Control Group } & \multicolumn{2}{c}{ Exogenous melatonin } & \multicolumn{2}{c}{ 16D: 8L } \\
& $\overline{\mathrm{x}}$ & $\mathrm{S}(\mathrm{X})$ & $\overline{\mathrm{x}}$ & $\mathrm{S}(\mathrm{X})$ & $\overline{\mathrm{x}}$ & $\mathrm{S}(\mathrm{X})$ \\
\hline C 4:0 & 2.64 & 1.2 & $2.41^{\mathrm{a}}$ & 1.6 & $2.97^{\mathrm{b}}$ & 1.8 \\
C 6:0 & 2.55 & 1.1 & $2.35^{\mathrm{a}}$ & 1.5 & $2.74^{\mathrm{b}}$ & 1.6 \\
C 8:0 & 2.75 & 1.3 & 2.74 & 1.7 & 2.96 & 1.7 \\
C 10:0 & $10.4^{\mathrm{a}}$ & 4.2 & $11.84^{\mathrm{b}}$ & 5.1 & 11.53 & 7.5 \\
C 12:0 & $6.8^{\mathrm{a}}$ & 2.8 & $8.78^{\mathrm{b}}$ & 3.9 & 7.89 & 3.9 \\
C 14:0 & $14.26^{\mathrm{a}}$ & 7.2 & $17.58^{\mathrm{b}, \mathrm{d}}$ & 8.2 & $15.78^{\mathrm{c}}$ & 8.1 \\
C 15:0 & 1.29 & 0.9 & 1.13 & 0.8 & 1.13 & 0.9 \\
C 16:0 & $28.26^{\mathrm{a}}$ & 10.9 & $30.13^{\mathrm{b}}$ & 11.8 & 29.25 & 13.1 \\
C 17:0 & 0.42 & 0.02 & 0.37 & 0.02 & 0.35 & 0.02 \\
C 18:0 & $4.60^{\mathrm{b}}$ & 1.9 & $3.29^{\mathrm{a}}$ & 2.1 & 4.06 & 2.1 \\
C 10:1 & 0.48 & 0.03 & 0.50 & 0.03 & 0.55 & 0.04 \\
C 14:1 & 0.57 & 0.02 & 0.59 & 0.04 & 0.61 & 0.05 \\
C 16:1 & 2.16 & 0.7 & 1.67 & 1.1 & 1.88 & 0.7 \\
C 17:1 & 0.26 & 0.02 & 0.21 & 0.01 & 0.24 & 0.01 \\
C 18:1 & $12.76^{\mathrm{b}}$ & 7.6 & $11.53^{\mathrm{a}}$ & 6.9 & 12.12 & 7.2 \\
C 18:2 & $2.36^{\mathrm{b}}$ & 0.9 & $1.87^{\mathrm{a}}$ & 0.9 & 2.04 & 0.8 \\
C 18:3 & 0.39 & 0.02 & 0.30 & 0.02 & 0.29 & 0.01 \\
CLA & $0.71^{\mathrm{b}}$ & 0.04 & $0.35^{\mathrm{a}}$ & 0.01 & 0.50 & 0.03 \\
SFA & $7.41^{\mathrm{b}}$ & 3.2 & $8.06^{\mathrm{a}}$ & 3.1 & 7.87 & 3.9 \\
MUFA & $2.71^{\mathrm{b}}$ & 1.9 & $2.38^{\mathrm{a}}$ & 1.7 & 2.54 & 0.6 \\
PUFA & 1.37 & 0.8 & 1.11 & 0.9 & 1.16 & 0.4 \\
\hline
\end{tabular}

CLA: conjugated linoleic acid, SFA: saturated fatty acid, MUFA: monounsaturated fatty acid, PUFA: polyunsaturated fatty acid 
Table 5

Changes of fat acid in sheep's milk in July, \%

\begin{tabular}{|c|c|c|c|c|c|c|}
\hline \multirow[t]{3}{*}{ Fatty acid } & \multicolumn{6}{|c|}{ Collection 4- July } \\
\hline & \multicolumn{2}{|c|}{$\begin{array}{c}\text { Group I } \\
\text { Control Group }\end{array}$} & \multicolumn{2}{|c|}{$\begin{array}{c}\text { Group II } \\
\text { Exogenous melatonin }\end{array}$} & \multicolumn{2}{|c|}{$\begin{array}{l}\text { Group II } \\
\text { 16D: 8L }\end{array}$} \\
\hline & $\bar{x}$ & $S(X)$ & $\bar{x}$ & $S(X)$ & $\bar{x}$ & $S(X)$ \\
\hline C $4: 0$ & 2.58 & 1.3 & $2.38^{\mathrm{a}}$ & 1.1 & $2.93^{b}$ & 0.9 \\
\hline C $6: 0$ & $2.48^{c}$ & 1.2 & $2.33^{\mathrm{a}}$ & 0.9 & $2.84^{\mathrm{b}, \mathrm{d}}$ & 0.8 \\
\hline C 8:0 & $2.58^{\mathrm{a}}$ & 1.3 & 2.61 & 1.2 & $3.07^{b}$ & 1.7 \\
\hline C 10:0 & $9.61^{\mathrm{a}}$ & 4.7 & 10.46 & 5.6 & $11.80^{\mathrm{b}}$ & 8.2 \\
\hline C 12:0 & $5.91^{\mathrm{a}}$ & 2.9 & $7.87^{b}$ & 4.2 & 7.31 & 3.7 \\
\hline C 14:0 & $12.64^{\mathrm{a}}$ & 6.8 & $16.71^{\mathrm{b}}$ & 8.6 & 15.80 & 9.1 \\
\hline C 15:0 & $1.46^{\mathrm{b}}$ & 0.8 & 1.10 & 0.9 & $0.86^{\mathrm{a}}$ & 0.09 \\
\hline C 16:0 & $27.27^{\mathrm{a}}$ & 11.9 & 28.89 & 12.3 & $29.81^{b}$ & 12.4 \\
\hline C 17:0 & 0.53 & 0.03 & 0.39 & 0.02 & 0.35 & 0.02 \\
\hline C 18:0 & 4.88 & 1.9 & 3.89 & 1.9 & 4.64 & 1.4 \\
\hline C 10:1 & 0.40 & 0.02 & 0.55 & 0.1 & 0.45 & 0.02 \\
\hline C 14:1 & 0.51 & 0.03 & $0.69^{b}$ & 0.2 & $0.34^{\mathrm{a}}$ & 0.06 \\
\hline C $16: 1$ & $2.22^{\mathrm{b}}$ & 0.8 & 1.80 & 0.7 & $1.01^{\mathrm{a}}$ & 0.3 \\
\hline C $17: 1$ & $0.38^{\mathrm{a}}$ & 0.02 & 0.23 & 0.01 & $0.14^{b}$ & 0.01 \\
\hline C $18: 1$ & 13.59 & 7.8 & 13.89 & 7.1 & 12.73 & 6.9 \\
\hline C18:2 & $2.95^{\mathrm{b}}$ & 0.9 & $1.56^{\mathrm{a}}$ & 0.9 & 2.04 & 0.8 \\
\hline C $18: 3$ & 0.40 & 0.02 & 0.42 & 0.1 & 0.36 & 0.01 \\
\hline CLA & $0.96^{\mathrm{b}}$ & 0.3 & 0.41 & 0.1 & $0.38^{\mathrm{a}}$ & 0.02 \\
\hline SFA & 6.99 & 2.8 & 7.67 & 3.3 & 7.94 & 3.4 \\
\hline MUFA & $2.93^{\mathrm{a}}$ & 1.7 & 2.74 & 1.8 & $2.44^{b}$ & 0.8 \\
\hline PUFA & $1.68^{\mathrm{a}}$ & 0.6 & 0.99 & 0.06 & $1.20^{\mathrm{b}}$ & 0.1 \\
\hline
\end{tabular}

CLA: conjugated linoleic acid, SFA: saturated fatty acid, MUFA: monounsaturated fatty acid, PUFA: polyunsaturated fatty acid

\section{Discussion}

The day length is an important factor in the initiation and maintenance of lactation as a modulator of melatonin and prolactin concentrations. It is the changes in prolactin secretion in lactating sheep that primarily affect the amount of milk produced, synthesis of milk proteins, fat and immunoglobulins (i.e. milk composition), and thus the quality and technological suitability of milk. Photoperiod is an important factor influencing animal productivity. It plays a particularly important role in short-day animals, in which day length has an effect on changes in melatonin and prolactin secretions (Misztal et al. 1996, Misztal et al. 2001). Studies by Sawicka et al. (1987) and Ciuryk et al. (2001) indicated that in seasonally breeding ewes milk composition i.e solids content, proteins and fat levels increased when lactation continued. The present study demonstrated that administration of exogenous melatonin and simulation of the short day had a significant effect on the chemical composition of milk and the level of fatty acids. The administration of melatonin implants during the long day reduced the average solids content. The present study showed that milk from Control group was characterized by lower proteins content compared to experimental groups. Ewes exposed to an artificial short photoperiod (16D:8L) and those with melatonin implants produced milk with higher fat level. However, the highest concentration of fat was noted in milk collected 
from ewes kept under an artificial short days condition (16D;8L). The results of our study are similar to data received by Auldist et al. (2007) who determined the effect of exogenous melatonin on milk yield and composition of milk from dairy grazing cows. Moreover, similarly to our results got from melatonin-implanted ewes and those kept under an artificial shortdays conditions, authors indicated that melatonin decreased lactose concentration in milk (Auldist et al. 2007). In the present study melatonin decreases lactose level after only 30 days of lactation. The present findings, especially those obtained for changes in protein content in the Control group, can be related to the studies by El-Saied et al. (1998) and Cappio-Borlino et al. (1997). In their findings, protein and fat content increased in Valle del Belice sheep during lactation. In seasonally breeding animals (sheep) melatonin modulates not only prolactin secretion but it is able to modify milk composition, as well. Furthermore, studies by Molik et al. $(2007,2008)$ showed that ewes milking during the long photoperiod could produce more milk than ewes milking under the short-day conditions. That suggest that melatonin can affect milk production in seasonally breeding ewes. The precise mechanism of action of melatonin is still unclear, however there are speculations that prolactin could be one of the factor which mediates of galactopoietic effects of the day-length on milk composition (Dahl et al. 2000).

In the present study, as lactation continued, in milk from Control group the content of SFA (saturated fatty acid) decreased and the content of PUFA (polyunsaturated fatty acid) increased. Implantation of exogenous melatonin and exposition of ewes to an artificial short days (16D:8L) caused decrease in MUFA (monounsaturated fatty acid) and PUFA content. Moreover, the present study revealed that as lactation began and continued, the levels of butyric, caproic and caprylic acids consistently decreased and the content of capric acid increased. A study by Bonczar (1989) and Wojtowski et al. 2001 and Meluchova et al. (2008) showed that towards the end of lactation, the milk from sheep had an increased content of C4:0, C6:0, C18:0, C18:1 and C18:3 fatty acids, and a decreased content of C8:0, C10:0, C12:0, C14:0, $\mathrm{C} 16: 0$ and $\mathrm{C} 18: 2$ acids.

It is worth to indicate that milk from the Control group had the highest level of CLA. The administration of melatonin via subcutaneous implants and an artificial short-days conditions reduced CLA content of milk and caused lower healthy dietary qualities of milk.

The present study showed that the introduction of biochemical and light modulation of photoperiod through increased melatonin secretion via subcutaneous implants and an artificial short-day condition can affect milk composition in seasonally breeding ewes. Melatonin not only decrease lactose concentration but also caused a significant deterioration in the fatty acid profile of milk. These results imply seasonal variations in milk composition common to Polish milking ewes which cannot be overridden by farming though diet or breeding system. Further studies are needed to confirm that phenomenon in order to make sheep milk production system more regular around the year together with better manufacturing properties of milk. 


\section{References}

Anifantakis EM (1986) Comparison of the physico-chemical properties of ewe's and cow's milk. FIL-IDF Bulletin, doc. 202, 42-53

Auldist MJ, Turner SA, McMahon CD, Prosser CG (2007) Effects of melatonin on the yield and composition of milk from grazing and dairy cows in New Zealand. J Dairy Res 74, 52-57

Bonczar G (1989) Study on the quality and processing suitability of sheep milk. Przegląd Mleczarski 11, 397400 [in Polish]

Bonczar G (2006A) Quality of hard-smoked cheese taking into account the evaluation of sheep milk and sheep milk whey. Mat. Szkol. Wydawnictwo Akademii Rolniczej w Krakowie 2, 18-22 [in Polish]

Bonczar G (2006B) Regional products from sheep milk in Poland and in the world. Wydawnictwo Akademii Rolniczej w Krakowie 2,23-29 [in Polish]

Borys B, Pisulewski PM (2001) Quality and possibility of modifying the health-promoting properties of food products from sheep. Roczniki Naukowe Zootechniki Suplement 11, 67-86 [in Polish]

Borys M, Pakulski T, Borys B, Pakulska E, Węgrzyn E (2006) The content and retention of some major and trace minerals in sheep's milk and cheese. Arch Tierz 49 Special Issue, 263-267

Budsławski J (1981) Outline of milk chemistry. PWRiL, Warszawa [in Polish]

Cappio-Borlino A, Portolano B, Todaro M, Macciotta NPP, Giaccone P, Pulina G (1997) Lactation curves of Valle del Belice dairy ewes for yields of milk, fat, and protein estimated with test day models. J Dairy Sci 11, 3023-3029

Carta A, Casu S, Usai MG, Addis M, Fiori M, Fraghi A, Miari S, Mura L, Piredda G, Schibler L, Sechi T, Elsen JM, Barillet $F$ (2008) Investigating the genetic component of fatty acid content in sheep milk. Small Rum Res $79,22-28$

Ciuryk S, Molik E, Bonczar G (1999a) Current status of milk utilization of sheep in the Krakow region based on research at the Department of Sheep and Goat Breeding of the University of Agriculture in Kraków. Zeszyty Naukowe Fundacja Rozwój SGGW 3, 61-69 [in Polish]

Ciuryk S, Molik E, Bonczar G (1999b) Yield and chemical composition of milk from prolific Olkuska sheep, Longwool sheep and hybrids sired by Charollais Rams. Zeszyty Naukowe Polskiego Towarzystwa Zootechnicznego 43, $73-79$ [in Polish]

Ciuryk S, Molik E, Pustkowiak H (2001) Changes in fatty acid and cholesterol levels in milk from Polish Longwool Sheep used for milk production. Roczniki Naukowe Zootechniki 12, 147-151 [in Polish]

Ciuryk S, Molik E, Kaczor U, Bonczar G (2004) Chemical composition of colostrum and milk of Polish Merino sheep lambing at different times. Arch Tierz Special Issue 47, 129-134

Dahl, GH, Buchanan BA, Tucker HA (2000). Photoperiodic effects on dairy cattle: Review. J Dairy Sci 83, 885-893

El-Saied UM, Carriedo JA, San Primitivo F (1998) Heritability of test day somatic cell counts and its relationship with milk yield and protein percentage in dairy ewes. J Dairy Sci 11, 2956-2961

Fischer A, Schalitz G, Behling C (2007) Breed-specific classification potentials of sheep in different grassland. Arch Tierz 50, 174-185

Haenlein GF, W (1996) Nutritional value of dairy products of ewes and goats milk. Sheep Dairy News 13, 10-16

Lucey J (1996) Cheesemaking from grass based seasonal milk and problems associated with late lactation milk. J Soc Dairy Tech 49, 59-64

Luna P, Fontecha J, Juarez M, de la Fuente MA (2005) Conjugated linoleic acid in ewe milk fat. J Dairy Res72, $415-424$

Mann J (1964) Determination of fatty acid composition of milk fat by dual column temperature programmed gas liquid chromatography. J Dairy Sci 47, 564-560

Mel'uchova B, Blaško J, Kubinec R, Górová R, Dubravská J, Margetín M, Soják L (2008) Seasonal variations in fatty acid composition of pasture forage plants and CLA content in ewe milk fat. Small Rum Res 78, 56-65 
Misztal T, Romanowicz K, Barcikowski B (1996) The role of melatonin in prolactin secretion in sheep Postępy Biologii Komórki 26, 117-123 [in Polish]

Misztal T, Romanowicz K, Barcikowski B (2001) Short - term modulation of prolactin secretion by melatonin in anestrous ewes following dopamine - and opiate receptor blockade. Experimental Clinic Endocrinology Diabets 109, 174-180

Molik E, Misztal T, Romanowicz K, Wierzchoś E (2006) The influence of length day on melatonin secretion during lactation in sheep. Arch Tierz 49, 359-364

Molik E, Misztal T, Romanowicz K, Wierzchoś E (2007) Dependence of the lactation duration and efficiency on the season of lambing in relation to the prolactin and melatonin secretion in ewes. Livestock Sci 107, 220-226

Molik E, Murawski M, Bonczar G, Wierzchoś E (2008) Effect of genotype on yield and chemical composition of sheep's milk. Anim Sci Paper and Reports 26, 211-218

Norms (1993) Nutrient requirements for cattle and sheep in the traditional system IZ Krakow, Poland [in Polish]

Olechnowicz J, Sobek Z, Jaskowski JM, Antosik P, Bukowska D (2010) Connection of somatic cell Mount and milk field as well as composition in dairy ewes. Arch Tierz 53, 95-100

Pakulski T, Borys B, Pakulska E (2006) The level of some bioactive components in the fat fraction of sheep's milk and cheese. Arch Tierz 49 SI, 317-324

Russel AJ, Doney JM, Gunn RG (1969) Subjective assessment of body fat in live sheep. J Agriculural Sci 72, 451-454

SAS (2000) SAS version 8.1. SAS Institute Inc., Cary, NC, USA

Sawicka J, Wodziak K, Paradzisz Z (1987) Chemical composition and some physical characteristics of market milk from Polish Longwool Sheep of the Pogórza type Zeszyty Naukowe Akademii Rolniczej w Krakowie 24, 15-31 [in Polish]

Szumacher-Strabel M, Potkanski A, Cieslak A (2001) Effect of protected FAT on fatty acid compositions and conjugated linolic acid level in meat and milk of sheep. Arch Tierz 44 Special Issue, 329-335

Walisiewicz-Niedbalska W, Piatkowska-Sokolova B, Lipkowski A, Bodkowski R, Kwiatkowski J, Gwardiak H (2001) Studies of conjugate linolic acid (CLA) in sheep milk fat. Arch Tierz 44 Special Issue, 322-328

Wojtowski J, Dankow R, Gut A, Pikuli J, Slosarz P, Stanisz M, Sreppa R (2001) Fatty acid composition and cholesterol of sheep and goat milk fat during lactation. Arch Tierz 44 Special Issue, 299-308 [in German]

Żegarska Z (1998) Milk fat as a component of human diet. Przegląd Mleczarski 10, 369-371 [in Polish]

Received 16 June 2010, accepted 23 January 2011.

Corresponding author:

Edyta Molik

email: email: rzmolik@cyf-kr.edu.pl

Department of Sheep and Goat Breeding, Biotechnology and Genomic Laboratory, Agricultural University of Kraków, al. Mickiewicza 24/28, 30-059 Kraków, Poland 